\title{
Cultivating Engaged Leadership Through a Learning Collaborative: Lessons From Primary Care Renewal in Oregon Safety Net Clinics
}

Carmit K. McMullen, PbD

Jennifer Scbneider, MPH

Alison Firemark, MA

James Davis, BA

Mark Spofford, PbD

Center for Health Research, Kaiser Permanente Northwest, Portland, Oregon

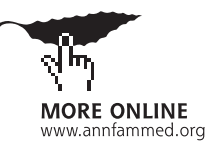

Conflicts of interest: authors report none.

\section{CORRESPONDING AUTHOR}

Carmit McMullen, PhD

Center for Health Research

Kaiser Permanente Northwest

3800 N Interstate Ave

Portland, OR 97227

carmit.mcmullen@kpchr.org

\begin{abstract}
PURPOSE The aim of this study was to explore how learning collaboratives cultivate leadership skills that are essential for implementing patient-centered medical homes (PCMHs).

METHODS We conducted an ethnographic evaluation of a payor-incentivized PCMH implementation in Oregon safety net clinics, known as Primary Care Renewal. Analyses primarily drew on in-depth interviews with organizational leaders who were involved in the initiative. We solicited perspectives on the history, barriers, facilitators, and other noteworthy factors related to the implementation of $\mathrm{PCMH}$. We reviewed and summarized transcripts and created and applied a coding dictionary to identify emergent leadership themes. We reviewed field notes from clinic site visits and observations of learning collaborative activities for additional information on the role of engaged leadership.
\end{abstract}

RESULTS Interview data suggested that organizations followed a similar, sequential process of Primary Care Renewal implementation having 2 phases-inspiration and implementation - and that leaders needed and learned different leadership skills in each phase. Leaders reported that collaborative learning opportunities were critical for developing engaged leadership skills during the inspiration phase of transformation. Facilitative and modeling aspects of engaged leadership were most important for codesigning a vision and plan for change. Adaptive leadership skills became more important during the implementation phase, when specific operational and management skills were needed to foster standardization and spread of the Primary Care Renewal initiative throughout participating clinics.

CONCLUSIONS The PCMH has received much attention as a way to reorganize and potentially improve primary care. Documenting steps and stages for cultivating leaders with the vision and skills to transform their organizations into PCMHs may offer a useful roadmap to other organizations considering a similar transformation.

Ann Fam Med 2013;11:S34-S40. doi:10.1370/afm.1489.

\section{INTRODUCTION}

$\mathrm{T}$ ransforming primary care delivery systems into patient-centered medical homes (PCMHs) requires fundamental changes to the culture and organization of primary care. Leadership plays an essential role in guiding such transformation. ${ }^{1}$ An evaluation of the National Demonstration Project, an implementation of the PCMH in 36 settings nationwide, suggested that leadership is more important for successful implementation than the installation of the technologic components (ie, patient registries) or the primary care pillars (ie, care coordination) that distinguish medical homes from traditional primary care settings. ${ }^{2,3}$ Engaged leaders can build practices with a strong core of resources, organizational structures, and clinical processes, as well adaptive reserve, which includes attributes such as "healthy relationship infrastructure, an 
alignment management model, facilitative leadership, and attention to the local environment." ${ }^{1 /\left(p^{583)}\right.}$ Engaged leaders can maximize internal and external opportunities for change. ${ }^{4,5}$

Research has suggested that learning collaboratives represent an inexpensive mechanism for supporting leaders in guiding primary care transformation. ${ }^{3} \mathrm{Sev}-$ eral articles and implementation guides have further described the elements of leadership that support PCMH implementation. ${ }^{1,6,7}$ After an extensive literature review and feedback from experts, Wagner and

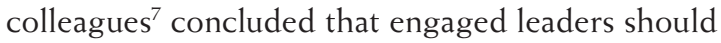
model the personal qualities they are encouraging in their organization (eg, persistence, willingness to take risks, attention to outcomes, and personal accountability). Leaders should adopt a facilitative style that empowers staff to create and experiment with solutions that will move the organization toward its goals. Finally, leaders should be adaptive by providing "visible and sustained leadership to lead overall culture change" as well as the concrete tools and strategies for achieving change. As this work suggests, it may not be possible to reduce the description of leadership's role in primary care transformation to a set of technical tasks. Rather, it seems to be more productive to think of engaged leadership as a journey or an ongoing challenge. ${ }^{7}$ As such, our report here of organizational leaders' perceptions of their journeys in specific PCMH implementations illustrates how leadership shapes PCMH implementation in different settings. ${ }^{7}$

In this article, we describe how a group of leaders launched PCMH implementation among 6 safety net organizations in Portland, Oregon. These leaders were supported through a learning collaborative convened by a nonprofit Medicaid health maintenance organization. These leaders described 2 phases of the journey-inspiration and implementation - and their descriptions pointed to a sustainable, replicable process for launching successful primary care transformation through learning collaboratives. Guided by the model of engaged leadership of Wagner et al, ${ }^{7}$ we summarize lessons and leadership skills that interview participants found essential for transforming their organizations, and specify ways in which the collaborative fostered elements of engaged leadership (modeling, facilitative, and adaptive leadership) differently as they moved from inspiration to implementation.

\section{METHODS}

\section{Setting}

CareOregon initiated Primary Care Renewal (PCR) in 2006 as an effort to implement PCMH in safety net clinics in the Portland metropolitan area. ${ }^{8}$ CareOregon is the largest Medicaid managed-care plan in Oregon. PCR was initiated under the plan's Care Support and System Innovation program, a funding mechanism to support improvement strategies that foster a culture of evidence-based practice and continuous improvement in provider organizations. Initially, 4 organizations participated in PCR, and 2 others joined soon after (Table 1).

By 2010, PCR clinics showed decreases in hospital admissions relative to non-PCR clinics paid by CareOregon, ${ }^{9}$ and recent internal performance assessments suggest that PCR has successfully reduced wait times for appointments, improved diabetes outcomes, and lowered the number of ambulatory-sensitive hospitalizations. All PCR provider organizations were given the highest level of certification in Oregon's new Patient-Centered Primary Care Home Program (http:// www.primarycarehome.oregon.gov).

The Center for Health Research, Kaiser Permanente Northwest, conducted an ethnographic evaluation of PCR that consisted of the following:

- Interviews with organizational leaders and key players in PCR that were recorded and transcribed;

- Observation of PCR activities such as steering committee meetings, trainings, and learning collaborative conferences that resulted in field notes and collection of artifacts (ie, agendas, training documents); and

- Rapid assessments ${ }^{10}$ at 6 clinics that incorporated observations of team-based care, meetings, interviews, and surveys. These assessments were conducted in 3 organizations: Virginia Garcia Memorial Health Care, Family Medicine at the Oregon Health \& Science University, and the Multnomah County Health Department.

Rapport and trust for the ethnographic research were facilitated by joint efforts to design and seek funding for this evaluation and by participating in steering committee meetings and learning collaborative sessions before interviews and clinic site visits to gain familiarity with the leaders and key players involved in PCR. Our report here draws primarily on the interviews with organizational leaders. All coauthors on this article participated in clinic-based assessments and analyzed the resulting data, including interim summaries of findings from each provider organization and review of detailed, transcribed field notes from observations of clinical care and meetings, brief interviews, and staff surveys. The Center for Health Research's institutional review board reviewed and approved this study.

\section{Overview of Learning Collaborative Activities}

We used interview and learning collaborative observation data to summarize the coaching resources of PCR organizations. In addition to convening regular meetings of PCR leaders, CareOregon provided support to 
Table 1. Characteristics of Primary Care Renewal Provider Organizations and Data Collected

\begin{tabular}{|c|c|c|c|c|c|}
\hline \multirow[b]{2}{*}{ Characteristic } & \multicolumn{5}{|c|}{ Organization } \\
\hline & VGMHC & MCHD & OHSU & Legacy Emanuel & Old Town Clinic \\
\hline Organization characteristics & $\mathrm{FQHC}$ & $\mathrm{FQHC}$ & $\begin{array}{l}\text { FQHC look-alike, rural } \\
\text { health clinic family } \\
\text { medicine department }\end{array}$ & $\begin{array}{l}2 \text { PCR clinics from } \\
\text { a large, nonprofit } \\
\text { health system }\end{array}$ & $\begin{array}{l}\text { FQHC; Health- } \\
\text { care for the } \\
\text { Homeless site }\end{array}$ \\
\hline Clinician FTEs (2011)a & 36.8 & 56.6 & $\begin{array}{l}14.9 \text { (Richmond); } 8.0 \\
\text { (Scappoose) }\end{array}$ & 3.2 plus residents ${ }^{b}$ & 6.12 \\
\hline Patient characteristics & $\begin{array}{l}\text { Many Spanish-speaking } \\
\text { patients; migrant work- } \\
\text { ers; diverse cultures } \\
\text { and languages; high- } \\
\text { volume pediatric care }\end{array}$ & $\begin{array}{l}\text { Diverse cul- } \\
\text { tures and } \\
\text { languages; } \\
\text { refugees }\end{array}$ & $\begin{array}{l}\text { Family medicine resi- } \\
\text { dency training sites; } \\
1 \text { urban, ethnically } \\
\text { diverse clinic; } 1 \text { rural } \\
\text { clinic }\end{array}$ & $\begin{array}{l}\text { Urban; internal } \\
\text { medicine resi- } \\
\text { dency training } \\
\text { site (at } 1 \text { clinic) }\end{array}$ & $\begin{array}{l}\text { Homeless indi- } \\
\text { viduals with } \\
\text { chemical } \\
\text { dependencies }\end{array}$ \\
\hline \multicolumn{6}{|l|}{ Study data } \\
\hline Leaders interviewed, No. & 1 & 2 & 1 & 1 & 1 \\
\hline Learning collaborative & Yes & Yes & Yes & Yes & Yes \\
\hline PCR steering committee & Yes & Yes & Yes & Yes & Yes \\
\hline \multicolumn{4}{|l|}{ Clinic site visit measures, No. } & $\mathrm{N} / \mathrm{A}$ & $\mathrm{N} / \mathrm{A}$ \\
\hline Interviews & 20 & 26 & 23 & - & - \\
\hline Field note pages & 181 & 293 & 218 & - & - \\
\hline Survey questionnaires & 57 & 51 & 71 & - & - \\
\hline Researcher days $^{d}$ & 15 & 23 & 16 & - & - \\
\hline \multicolumn{6}{|c|}{$\begin{array}{l}\text { FQHC = Federally Qualified Health Center; FTE = full-time equivalent; } M C H D=\text { Multnomah County Health Department; N/A = not applicable; OHSU = Oregon Health } \\
\text { \& Science University; PCR = Primary Care Renewal; VGMHC = Virginia Garcia Memorial Health Center. }\end{array}$} \\
\hline \multicolumn{6}{|c|}{$\begin{array}{l}\text { a All but Legacy Emanuel's data come from } 2011 \text { Uniform Data Set reporting to the Health Resources and Services Administration, compiled by the Oregon Primary } \\
\text { Care Association. (See also http://bphc.hrsa.gov/uds/view.aspx?q= rlgEyear=2011.) }\end{array}$} \\
\hline \multicolumn{6}{|c|}{ b From Legacy Emanuel's third-quarter 2011 PCR Status Report to CareOregon. } \\
\hline \multicolumn{6}{|c|}{$\begin{array}{l}\text { c A total of } 7 \text { learning collaborative and steering committee observations yielded } 58 \text { pages of field notes, which we could not separate by organization because mul- } \\
\text { tiple PCR organizations attended these activities. }\end{array}$} \\
\hline \multicolumn{6}{|c|}{$\begin{array}{l}\text { Researcher days were calculated by number of team members present for each day or half-day of observation. Typically, } 3 \text { or } 4 \text { team members were present at any } \\
\text { given time during a site visit. }\end{array}$} \\
\hline
\end{tabular}

participating practices by sharing performance data and by sponsoring (with partners) an ongoing learning collaborative in which PCR participants and other safety net clinics across Oregon shared ideas and best practices about primary care transformation. A formal learning center was set up at CareOregon headquarters to serve as a venue where experienced practice leaders conducted periodic learning sessions (initially every 6 weeks, with decreasing frequency as PCR was implemented). On some days, more than 100 people attended these sessions.

During the initial phases of PCR, CareOregon helped train 2 process improvement coaches in each participating organization. One coach was a member of the clinical team piloting team-based care, and another coach was a member of management or administration. The organizations' quality improvement coaches met on a regular basis to go over Plan, Do, Study, Act (PDSA) cycles, review clinical and process performance measures, and strategize the most effective implementation processes for transforming care. This Data and Reporting Workgroup originally met on a biweekly basis with a consultant and the senior data analyst for CareOregon. Later, the group met monthly with project staff of CareOregon as an ongoing work- ing group to continually research and share best practices with participating sites.

Starting with a single pilot team in a clinic, each organization developed workflows for PCR. Pilot teams met every 6 weeks to share lessons learned. After 8 months, teams began to spread the PCR model to other clinicians in their clinic, and over time to other clinics in their organization.

\section{Data Collection and Analysis}

Two members of the research team (C.K.M. and M.S.) conducted and recorded 9 semistructured, in-person interviews between November 2010 and November 2012. These audio-recorded interviews were approximately 1 hour in duration and were professionally transcribed. Interviews were conducted in researchers' or participants' offices on the basis of participant preference. We solicited respondents' input on the history, barriers, facilitators, and other important factors relating to the implementation of PCR (see Supplemental Appendix 1, available online at http://annfammed. org/content/11/Suppl_1/S34/suppl/DC1 for sample interview guide). We interviewed the 3 individuals in CareOregon who had the most in-depth knowledge of the PCR initiative. In addition, we sought to inter- 
view at least 1 member of the PCR steering committee from each PCR organization and purposefully selected participants to represent a diversity of operational and clinical leadership positions (Table 2). ${ }^{11,12}$

When all coauthors (except J.S.) had reviewed and summarized interview transcripts to identify emergent themes, it became clear that leadership and acquiring new leadership skills were important themes. We noticed that each interviewee identified a similar, sequential process of implementation having 2 phases - inspiration and implementation-and that leaders reported needing and learning different leadership skills in each phase. To explore this finding more deeply, 2 authors (A.F. and J.S.) read through the interviews, identified text segments pertaining to leadership concepts, and then analyzed the text segments to create summaries of leadership themes. They reconciled their summaries as a reliability check. After this analysis, we turned to the literature on leadership's role in primary care transformation and explored how the interview data could be informed by theories of engaged leadership. ${ }^{7}$

To increase the credibility and trustworthiness of our findings, we used so-called member checking at various phases of data analysis. Interim reports from clinic site visits and this article were reviewed by organizational leaders. Our ethnography also used triangulation techniques in data collection and analysis. We drew on multiple types of data sources (interviews and observations) collected from stakeholders represent- ing multiple organizations, roles, and perspectives. ${ }^{13,14}$ Although this article focuses on data from leader interviews, we also triangulated our findings by drawing on knowledge derived from other study activities.

\section{RESULTS}

In our interviews, we asked organizational leaders to tell the story of PCR implementation from their perspective. Almost uniformly, they told of a 2-phase journey that started with inspiration and continued with implementation. Below, we distill their stories and highlight the ways that CareOregon's collaborative approach to practice transformation fostered elements of engaged leadership, including modeling, facilitative, and adaptive leadership.

\section{Phase 1: Inspiration}

PCR leaders reported that by 2006, Portland area safety net leaders recognized the need for major transformation of health care delivery. CareOregon initiated PCR as part of a broad effort to transform primary care into a paradigm emphasizing population health and fiscal sustainability. The medical director and chief executive officer of CareOregon solicited examples of a primary care system that "really got this

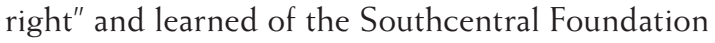
(SCF), an innovative Alaska Native-owned, nonprofit health care organization that had transformed its care under the PCMH model. In August 2006, CareOregon sponsored a trip for 30 senior leaders from CareOregon and local primary care organizations to Alaska for what CareOregon's medical director described as an "emotional," "empowering," and "religious experience" in that "the general feeling was - this is why I went into medicine." He reported that the group's thinking quickly turned from "is this something we should do?" to "how could we not do this?"

The group began setting a vision for how to bring $\mathrm{PCMH}$ back to Portland by agreeing on 5 pillars of $\mathrm{PCMH}$ : customerdriven care, proactive panel management, integrated behavioral health, team-based care, and barrier-free access. CareOregon's medical director reflected that his organization's executive leadership believed strongly 


\section{Table 3. Inspiration Phase: Key Themes According to Leadership Element}

\begin{tabular}{|c|c|c|}
\hline Modeling Leadership & Facilitative Leadership & Adaptive Leadership \\
\hline $\begin{array}{l}\text { Before deciding to embark on PCR, regional } \\
\text { safety net clinic leaders had similar personal } \\
\text { drive and vision for their organizations: a pop- } \\
\text { ulation-based approach to care that enhanced } \\
\text { the patient care experience. } \\
\text { All PCR participants shared a deep dissatisfac- } \\
\text { tion with the current state of primary care and } \\
\text { desire for transformation. } \\
\text { All PCR leaders had a strong leadership vision } \\
\text { that reflected a desire to put systems and } \\
\text { structures in place to foster nonjudgmental, } \\
\text { patient-centered care. }\end{array}$ & $\begin{array}{l}\text { Leaders codesigned } 5 \text { pillars and the pay- } \\
\text { ment method to align resources to allow } \\
\text { the model to emerge and function. } \\
\text { Leaders saw collaboration, empowerment, } \\
\text { and codesign as essential during the } \\
\text { piloting phase. } \\
\text { All levels of the organization, especially } \\
\text { frontline staff, were included as thought } \\
\text { partners in the process of pilot testing } \\
\text { (and later implementing) the model. } \\
\text { Pilot teams were composed of champions. }\end{array}$ & $\begin{array}{l}\text { Steering committee had a combination of } \\
\text { closed meetings only for PCR participants } \\
\text { and open meetings with other community } \\
\text { partners or advisors. } \\
\text { Recognizing that external partnerships and } \\
\text { payment reform were required for PCR } \\
\text { success, CareOregon and steering commit- } \\
\text { tee members also advocated for statewide } \\
\text { payment and health care reform. }\end{array}$ \\
\hline
\end{tabular}

in empowering the nascent collaborative of leaders, staff, and their patient communities to set a vision for change, codesign plans for implementation, and work collaboratively to set quality metrics and financial incentives to enable the transformation to progress. He realized that exporting the SCF model would require a collaborative and intentional effort across all of the participating organizations.

Participating organizations established a learning collaborative in which representatives from each organization tried to reproduce what they had observed at SCF. The organizations were charged with trying to creatively implement concepts, principles, and practices to achieve the 5 pillars in their own unique environments while working together toward common practices, measures, and metrics for PCR. Leaders reflected on different barriers during this early phase. One medical director, whose clinic serves many homeless patients, reflected that PCR's approach to collaborative design and implementation tended to minimize the culture of each organization. She believed that the collaborative approach somewhat limited local empowerment, saying that instead of asking "how does the culture of your organization, but more importantly the culture of your patients...inform your site...we just started designing." Another leader, who recognized that transformation was necessary, felt restricted by the financial difficulties that her large provider organization was facing. Her focus was to internally communicate the vision for PCR while stabilizing her organization's financial situation so that when PCR was spread beyond pilot teams, they would have the capacity to handle the change.

Table 3 summarizes how the PCR collaborative cultivated engaged leadership during the inspiration phase of PCR. Information was reported in interviews with organizational leaders or observed in other study activities. Key themes of engaged leadership during the inspiration phase are presented according to the 3 types of engaged leadership as identified by Wagner and colleagues. ${ }^{7}$

\section{Phase 2: Implementation}

Our interviewees reported that by 2009, they were struggling to standardize and spread the 5 pillars of PCR in their clinics. Looking for tools to reengineer their practices, some organizations started using Lean management techniques ${ }^{15}$ for quality improvement and looked for best practices in using them for primary care transformation.

Working through the Alliance of Commercial Health Plans, leaders at CareOregon reached out to Group Health Cooperative, an integrated delivery system and health maintenance organization that was using Lean techniques to transform its delivery system. Enthusiasm among the struggling PCR group was renewed on hearing about Group Health's approach. By visiting and consulting with Group Health representatives, PCR participants realized they needed a sequential, stepwise model of change facilitated by specific management techniques emphasizing workflows, identifying redundancies and waste, and focusing on quality process and target measures. These objectives resonated with CareOregon's stated philosophy of encouraging intentionality and accountability among provider organizations. CareOregon's manager of primary care projects reflected that their learning from Group Health "was not so much the model, but the how. That here's the level of standardization. Here's the way you communicate it. Here's how you build the time and space for people to engage...here's how to wake up, and stay on point." Although she understood that Group Health's level of effort "could be duplicated by safety net practices, or even a collaborative of them," she was inspired by Group Health's willingness to "dive into the nitty-gritty of operations" and to create change packages that would be useable for the PCR clinics. 
Table 4 draws on leader interviews and our ethnographic observations to illustrate how elements of engaged leadership (modeling, facilitative, and adaptive leadership) were fostered during the implementation phase of PCR. We identify ways that the learning collaborative fostered each facet of engaged leadership.

\section{DISCUSSION}

We describe here one payor's efforts to support primary care transformation in safety net clinics in the Portland, Oregon, metropolitan area. The story demonstrates how CareOregon cultivated engaged leadership with relatively scarce resources among its partner organizations by convening a group of organizational leaders who codesigned their own transformation and became trusted partners for sharing lessons and overcoming implementation hurdles. CareOregon sponsored early efforts that brought leaders together to collaboratively articulate a shared vision of 5 pillars of patient-centered care. This step was the first in moving the group toward pilot testing a medical home model. CareOregon allowed a shared vision to unfold with extensive participation that set the tone for a facilitative leadership orientation that has permeated PCR ever since. Medical directors and executive leaders hoped that implementation would follow from their clearly articulated vision supported by modest financial incentives, and although they obtained buy-in and initial success in pilot testing innovations, they soon realized that sustaining primary care transformation would require deep changes to the structure and operation systems of their organizations. In a sense, they lacked an important element of adaptive leadership: the tools for achieving change. CareOregon's support of a data and reporting workgroup, site visits to Group Health, and sustained consulting relationships with organizations that could provide concrete implementation lessons all filled the gaps in adaptive leadership that became apparent after the initial, inspiration phase.
PCR participants were subsequently able to adopt a more systematic outline of clear quality improvement and workflow practices, data capture and measurement, and goal setting. The initial gap in implementation skills may have been a barrier to implementation, yet the collaborative may not have succeeded without the open-ended, initial step of articulating a vision inspired by the possibility to improve health outcomes, lower costs, and increase patient and clinician satisfaction.

The early process of creating and implementing the medical home model was driven by the intentions, excitement, and strong advocacy of the pioneering leaders. To allow for creativity and flexibility in this process, they did not place many rules around how to make the medical home model work. As implementation began and insights emerged, the organizations introduced more structure and standardization so that PCR could continue to adapt and be sustained. Because of this gradual process, it is possible that a fully developed implementation plan would not have cultivated facilitative leadership. That is, without the "incubator" experience that organizational leaders shared, they would not have developed the passion for transformation or the conviction to model personal qualities that they were trying to instill within their organizations. These facilitative and modeling aspects of engaged leadership may not have been cultivated by a rigid rollout of a predetermined intervention.

We took an ethnographic, case study approach to understanding PCMH implementation through the lens of CareOregon's efforts to foster leadership among participating organizations. A limitation of this analysis is that we may have minimized the complexity of the undertaking by focusing on 1 aspect of PCR. We attempted to maximize the validity and "trustworthiness" of our interpretations through member checking and triangulation, however. Subsequent analyses from the ethnography will focus on how implementation varied by organization and how teams and organizational structures were tailored to fit each

\section{Table 4. Implementation Phase: Key Themes According to Leadership Element}

\begin{tabular}{|c|c|c|}
\hline Modeling Leadership & Facilitative Leadership & Adaptive Leadership \\
\hline $\begin{array}{l}\text { Coaching in Lean management } \\
\text { pushed leaders to formalize } \\
\text { rounding visits to clinic-level } \\
\text { leaders. Top leaders noted } \\
\text { that these rounds seemed } \\
\text { overly structured and not } \\
\text { "friendly," but clinic-level } \\
\text { management liked leaders' } \\
\text { interest in the details of their } \\
\text { work and what they were } \\
\text { expected to present when } \\
\text { top leaders visited the clinic. }\end{array}$ & $\begin{array}{l}\text { Leaders purposefully involved key staff-directors, qual- } \\
\text { ity managers, physician leaders, frontline medical and } \\
\text { allied health professionals, and office personnel- } \\
\text { throughout their organizations in learning collaborative } \\
\text { training sessions. } \\
\text { The leaders and champions viewed themselves from the } \\
\text { beginning as advocates of the model, cocreating a } \\
\text { change process through inspiration and advice, rather } \\
\text { than through a top-down approach of dictating change. } \\
\text { Communication structures were organized to avoid a top- } \\
\text { down approach and encourage participation of all staff. }\end{array}$ & $\begin{array}{l}\text { Learning collaborative seminars and workshops } \\
\text { spread expertise from experts to beginners. } \\
\text { Learning collaborative seminars provided } \\
\text { dedicated time for organizations to meet by } \\
\text { themselves to discuss lessons, and align and } \\
\text { set organizational priorities. } \\
\text { Participation in Safety Net Medical Home Ini- } \\
\text { tiative focused on development of technical } \\
\text { expertise. } \\
\text { Metrics underlying reimbursement incentives } \\
\text { were continually reviewed in steering com- } \\
\text { mittee meetings as implementation matured. }\end{array}$ \\
\hline
\end{tabular}


organization's unique characteristics. Our ethnographic evaluation also did not systematically address quantitative outcomes of PCR as an intervention, but these outcomes were evaluated by another arm of our study and is reported separately. ${ }^{9}$ Finally, a variety of contextual factors may have affected PCR implementation (see Supplemental Appendix 2: Context, avail-

able online at http://annfammed.org/content/11/ Suppl_1/S34/suppl/DC1).

Homer and Baron have written that scaling up primary care transformation requires a shift away from "intensive boutique effort $[\mathrm{s}]$ in hothouse demonstration program $[\mathrm{s}]$ " and that "coaching practices through the process [should] become more of a technical task... than the art form now practiced by highly skilled professionals." ${ }^{1(\mathrm{p} 628)}$ Reflecting on the PCR initiative, it may be a mistake to approach primary care transformation as an essentially technical task. Although expensive practice coaching may not be scalable, a stepwise approach that cultivates facilitative and modeling aspects of leadership before technical expertise may be a scalable model for dissemination of the medical home. CareOregon's facilitation of PCR was not without obstacles or mistakes, but the basic approach toward facilitating inspiration followed by partnering for implementation expertise holds promise as a replicable model for supporting the profound changes in primary care culture that comprise transformation to a patient-centered medical home.

To read or post commentaries in response to this article, see it online at http://www.annfammed.org/content/11/Suppl_1/S34.

Key words: patient-centered medical home; engaged leadership; safety net clinics; transformation; organizational innovation; primary care; practice-based research

Submitted June 21, 2012; submitted, revised, December 5, 2012; accepted December 27, 2012.

Funding support: Funding for this research was provided by the Agency for Healthcare Research and Quality (grant 1R18HS019146).

Disclaimer: The content is solely the responsibility of the authors and does not necessarily represent the official views of the Agency for Healthcare Research and Quality.

Acknowledgments: This research would not have been possible without the generous cooperation of leaders, clinicians, and staff at Multnomah County Health Department, Virginia Garcia Memorial Health Centers, and the Richmond and Scappoose clinics at Oregon Health \& Science University. Members of the Primary Care Renewal Steering Committee welcomed us to their meetings and activities, and shared openly the successes and challenges of the PCR initiative. Debra Read at CareOregon answered many questions along the way. We also thank David Labby and Sally Retecki from CareOregon for their guidance throughout the project and their thoughtful review of this manuscript. Richard Meenan and David Mosen have been integral partners in this research, and Kevin Lutz provided editorial assistance.

\section{References}

1. Homer CJ, Baron RJ. How to scale up primary care transformation: what we know and what we need to know? J Gen Intern Med. 2010;25(6):625-629.

2. Nutting PA, Miller WL, Crabtree BF, Jaén $C R$, Stewart EE, Stange $K C$. Initial lessons from the first national demonstration project on practice transformation to a patient-centered medical home. Ann Fam Med. 2009;7(3):254-260.

3. Crabtree BF, Nutting PA, Miller WL, Stange KC, Stewart EE, Jaén CR. Summary of the National Demonstration Project and recommendations for the patient-centered medical home. Ann Fam Med. 2010;8(Suppl 1):S80-S90, S92.

4. Nutting PA, Crabtree BF, Miller WL, Stewart EE, Stange KC, Jaén CR. Journey to the patient-centered medical home: a qualitative analysis of the experiences of practices in the National Demonstration Project. Ann Fam Med. 2010;8(Suppl 1):S45-S56, S92.

5. Wang MC, Hyun JK, Harrison M, Shortell SM, Fraser I. Redesigning health systems for quality: lessons from emerging practices. Jt Comm J Qual Patient Saf. 2006;32(11):599-611.

6. Powell J, loranta S, Chaufournier R, Daniel D. Engaged leadership implementation guide: strategies for guiding PCMH transformation from within. In: Burton T, ed. Safety Net Medical Home Initiative. Seattle, WA: Qualis Health and the MacColl Institute for Healthcare Innovation at the Group Health Research Institute; 2012

7. Wagner EH, Coleman K, Reid RJ, Phillips K, Abrams MK, Sugarman $J R$. The changes involved in patient-centered medical home transformation. Prim Care. 2012;39(2):241-259.

8. US Department of Health and Human Services. Agency for Healthcare Research and Quality. Health Care Innovations Exchange. Clinics adopting plan-supported medical home model enhance access, improve quality, and reduce admissions among Medicaid managed care enrollees. http://www.innovations.ahrq.gov/content. aspx?id=2584. Accessed October 1, 2012.

9. Meenan RT, Mosen D, Luke S, Perrin NA. Evaluating primary care renewal in Oregon's safety net clinics: quantitative findings from CareOregon's (CO) adult Medicaid population. Presented at AHRQ Annual Conference, Bethesda, MD, September 2012.

10. Ash JS, Sittig DF, McMullen CK, Guappone K, Dykstra R, Carpenter J. A rapid assessment process for clinical informatics interventions. AMIA Annu Symp Proc. 2008;Nov 6:26-30.

11. Erlandson D, Harris E, Skipper B, Allen S. Doing Naturalistic Inquiry: A Guide to Methods. Thousand Oaks, CA: Sage Publications; 1993.

12. Morse JM, Field PA. Qualitative Research Methods for Health Professionals. Thousand Oaks, CA: Sage Publications; 1995.

13. Lincoln YG, Guba EG. Naturalistic Inquiry. Newberry Park, CA: Sage Publications; 1985.

14. Denzin N, Lincoln YS. The Sage Handbook of Qualitative Research Thousand Oaks, CA: Sage Publications; 2005.

15. Joosten T, Bongers I, Janssen R. Application of Lean thinking to health care: issues and observations. Int J Qual Health Care. 2009; 21(5):341-347. 